Fikrah: Jurnal Ilmu Aqidah dan Studi Keagamaan

ISSN 2354-6147 EISSN 2476-9649

Tersedia online di: journal.stainkudus.ac.id/index.php/fikrah

DOI: 10.21043/fikrah.v5i1.1769

\title{
Peranan Aliran Murjiah Dalam Membangun Kehidupan Toleransi Di Masa Modern
}

\author{
Muhamad Nurudin \\ STAIN Kudus, Kudus, Indonesia \\ muhamadnurudin70@gmail.com
}

\begin{abstract}
Abstrak
Toleransi adalah komponen penting dalam membangun masyarakat plural yang bertujuan menciptakan kehidupan harmonis tanpa membedakan satu sama lain. Terutama di era modern, ketidakmunculan sikap toleransi dapat berpotensi memecahbelah kesatuan. Apalagi dalam konteks berbangsa, seperti Indonesia. Kesadaran akan keragaman dalam berpikir, bersikap dan berperilaku akan menimbuhkan kehidupan yang harmonis dan toleransi, seperti kelompok Murji'ah. Penelitian ini menggunakan metode kualitatif yang bersifat library research dengan menggunakan literatur Islam sebagai rujukan utama. Hasil kajian menyatakan bahwa pertama, perbedaan dalam dunia pemikiran Islam sudah lama berkembang. Kedua, adanya ajaran toleransi yang ditawarkan oleh kelompok Murji'ah. Meskipun dalam perkembangannya kelompok ini terbagi menjadi dua kelompok besar yaitu kaum moderat (mutawasith) dan ektrim (mutasaddid). Sejak kaum Murji'ah tidak lagi tumbuh sebagai aliran yang dinamis, tetapi berubah menjadi kelompok pasif. Meskipun demikian watak aslinya tetap nampak yaitu sikap toleran.
\end{abstract}

Kata Kunci: Aliran Murji'ah, Toleransi, Era Modern 


\begin{abstract}
This paper explores the tolerance in the modern era. Tolerance is an important component in building a plural society aiming at living together without being distinguished from each other. Conversely, the lack of tolerance has the potential to threaten the unity especially in the context of the nation, like Indonesia. The awareness of diversity in thinking and acting will add harmonious life and tolerance, such as the Murji'ah group. This research used qualitative methods that are library research by using Islamic literature as the main reference. Therefore, it can be said that the difference in the world of Islamic thought has long been developed. It is in line with the teachings offered by the Murji'ah group. Although in its development this group is divided into two major groups namely the moderates (Mutawasith) and extreme (Mutasaddid). Since the Murji'ah no longer grew as a dynamic stream, but turned into a passive group. Nevertheless, the original character remains visible that is a tolerant attitude.
\end{abstract}

Keywords: Murji'ah, Tolerance, Modern Era

\title{
Pendahuluan
}

Keutuhan bangsa Indonesia terusik akibat munculnya berbagai gerakan seperti konsep khilafah (pemerintahan), larangan kepemimpinan selain kaum muslim, dan issue bahaya latent G $30 \mathrm{~S} / \mathrm{PKI}$ akhir-akhir ini. Isu-isu tersebut berawal dari terjadinya perbedaan sikap politik pada Pemilihan Kepala Daerah (Pilkada) Provinsi DKI Jakarta pada tahun lalu, dan terus berlangsung hingga proses pemilihan Presiden tahun 2019 mendatang. Konflik tersebut muncul akibat adanya calon yang berbeda visi, misi, organisasi dan keyakinan lalu menimbulkan perbedaan sikap dan pandangan di antara para elit kekuasaan hingga masyarakat pemilih. Peristiwa tersebut menimbulkan konflik yang membahayakan terhadap kelangsungan persatuan dan kesatuan bangsa Indonesia. Sebagai contoh, ada larangan dari masyarakat tertentu untuk mensholati jenazah orang yang memilih gubernur nonmuslim, materi ceramah pengajian berisi lebih mengedapankan materi bernuansa kampanye daripada tema dakwah yang lain dsb.

Perbedaan yang menimbulkan konflik juga terjadi dalam sejarah perkembangan teologi Islam. Konflik (firqah) yang terjadi juga lebih bernuansa politik daripada hal yang lain dan itu tidak teratasi secara tuntas. Sejak terjadi perang Shiffin pada tahun 40 $\mathrm{H}$ antara khalifah Ali bin Abu Talib Ra. dengan gubernur Damaskus Muawiyyah bin Abu Sufyan, lalu disusul perebutan kekuasaan antara Bani Umayyah dengan Abbasiyyah. Pertikaian politik tersebut lalu merembet pada bidang keaqidahan yang menimbulkan perbedaan golongan seperti antara faham Mu'tazilah, Jabariyyah, Murji'ah, dan Ahlussunnah. 
Konsep Islam sangat menganjurkan sikap toleran (al-hanifiyyah as-samhah), secara umum adalah sebagai berikut; pertama, anjuran untuk tidak memaksakan kehendak kepada orang lain (QS al-Baqarah: 256), kedua, anjuran untuk mengadakan musyawarah (as-syura') jika terjadi konflik, ketiga menghargai perbedaan (at-tasamukh) jika tidak mungkin melakukan kompromi (Al-Kafirun: 6). Tasamukh adalah sikap yang sangat penting diaplikasikan pada masa modern seperti sekarang ini. Indonesia memiliki berbagai macam perbedaan mulai dari suku, ras, agama sampai perbedaan dalam hal politik. Ketidakmampuan menerima perbedaan bagi Indonesia dapat mengganggu persatuan dan distabilitas keamanan negara sehingga sangat berbahaya bagi keutuhan negara Repubik Indonesia (RI). Sebelum para tokoh nasional Indonesia mengamalkan sikap toleran, para tokoh aliran Murji'ah telah mengembangkan paham tersebut. Golongan ini telah mampu menjembatani pertikaian antara kelompok Syi'ah dan Khawarij, sehingga pemerintahan Bani Umayyah dapat berkembang baik. Mereka dapat meredam gejolak emosi publik yang sangat mengancam kelangsungan persatuan umat. Namun dibalik sikapnya itu, mereka dianggap oportunis karena menerima adanya perbedaan paham teologi yang ada, terutama antara kaum Syi'ah, Khawarij, dan Mu'tazilah. Bahkan juga dituduh oportunis dalam menyikapi perbedaan aliran politik antara kaum Syi'ah dan Khawarij.

Murji'ah adalah salah satu paham teologi Islam sangat tua karena telah muncul sejak abad pertama Hijriyah. Mengingat kelahirannya dari kalangan awam yang mengalir secara alamiah, maka pendirinya tidak diketahui dengan pasti. Meskipun pada akhirnya muncul tokoh, Gailan ad-Dimasyqy (Islam, 2002). Golongan ini lahir sebagai sintesa atas munculnya dua kelompok ekstrem, yaitu Khawarij dan Syi'ah. Khawarij sangat ekstrim dalam memahami makna ajaran Islam karena terfokus pada makna lahiriyah suatu dalil. Akibatnya sulit menerima kelompok lain yang memahami dengan bentuk yang lain. Di sisi lain kaum Syi'ah sangat longgar dalam menerima ta'wil ayat, terutama yang dilakukan para pemimpinnya. Bahkan segala perilaku pemimpin mereka dianggap bagian dari wahyu.

Menghadapi pertentangan kedua kelompok di atas, Murjiah berusaha mengambil jalan tengah (kalimah as-sawa'), yaitu toleran dengan cara menghargai adanya perbedaan. Kelahiran aliran ini pada mulanya berangkat dari persoalan politik, 
yaitu antara kelompok yang menolak kepemimpinan Mu'awiyah bin Abu Sufyan dengan pendukungnya. Pada waktu muncul kelompok baru yang netral dalam menghadapi perbedaan sikap politik. Mereka bersikap apatis, karena tidak mau terlibat langsung dalam pertentangan, menerima kepemipinan Mu'awiyah sebagai khalifah denga menyerahkan urusan kepada Allah. Sebab, secara realitas beliau telah menjadi penguasa umat Islam serta mampu mengendalikan roda pemerintahan dengan baik (Nasution, 2011).

Selain terkait dengan politik, golongan Murji'ah juga berusaha memasuki jalur akidah. Untuk itu mereka membangun pahamnya dengan mengambil beberapa ayat dan hadis tentang kekuasaan, Pengetahuan dan kebenaran Allah sebagai zat yang Maha Sempurna. Sebab, di dunia tidak ada satupun kelompok manusia yang dapat mengetahui makna ayat dan hadis nabi secara mutlak. Jika terjadi perbedaan pendapat, langkah selanjutnya dilakukan kesepakatan (ijma'), apabila cara ini tidak bisa diatasi, langkah berikutnya adalah bersikap toleransi dengan menghargai perbedaan paham untuk menghindari perpecahan umat.

Sebagai kelompok mritas pengikutnya beragam dari kelompok elit hingga kaum awam (grassroot), paham Murji'ah mudah dicerna masyarakat. Menyadari para pengikutnya kaum awam, maka kelompok Murji'ah tidak mau terlibat langsung dalam pertikaian politik, mereka jenuh melihat konfliks yang terus berkepanjangan. Untuk itu, mereka mengambil sikap pasrah dengan menyerahkan hukum "kafir" tidaknya para pelaku dosa besar kepada Tuhan. Akibanya, para musuhnya menyebut kelompok ini dengan nama Murji'ah, yaitu golongan yang menyerahkan segala urusan keimanan kepada Allah SWT. Zat yang Maha Tahu isi hati setiap manusia; apakah beriman atau kafir.

Sikap toleransi yang berkembang di kalangan masyarakat awam (grassroot) ternyata mampu menumbuhkan stabilitas nasional yang mantap, apalagi pada masa pemerintahan Mu'awwiyyah bin Abu Sufyan, suasana negara dalam keadaan damai (Mahmud an-Nasr). Kenyataan ini dapat bertahan selama sembilan puluh tahun, suatu periode yang cukup panjang dikaitkan dengan kondisi umat Islam pada waktu itu. 
Ada hal menarik terkait dengan sikap toleransi yang dipegang kaum Murji'y, yaitu kelapangan mereka ketika dikaitkan dengan teologi Murji'ah. Menurut mereka seseorang yang terlibat dalam pertikaian politik padahal mereka orang-orang yang siqah (dapat dipercayai), maka mereka tidak mungkin keluar dari jalan yang benar. Oleh karenanya Murji'ah tidak mau menyalahkan siapa saja di antara para tokoh tersebut. Untuk itu segala persoalan diserahkan kepada Allah SWT maha pengampun (Nasution, 2011). Dibalik sikap toleran kaum Murji'ah di atas, terkesan mudah “diperalat” oleh para elit politik tertentu untuk melegalkan kebijakan dan kelangsungan pemerintahannya. Maka dari itu melalui karya ini penulis tertarik membahas masalah ini guna mengetahui sumbangan kaum Murji'ah terhadap persoalan kehidupan bertoleransi di zaman modern.

\section{Seputar Kelahiran Murjiah}

Berbicara tentang suatu aliran, tidak terlepas dari arti bahasa dari nama aliran itu. Nama tersebut ada yang berasal dari kelompoknya. Namun secara faktual, ketika berbeda dengan tujuan yang dimaksudkan, maka lahirlah sebutan yang dilabelkan orang lain, seperti pada golongan Mu'tazilah, Jabariyah, Khawarij, dan Murjiyah. Hal yang sama juga terdapat pada golongan Murji'ah. Kelompok Murji'ah tidak mengatakan seperti itu, melainkan sebagai kelompok muslimin atau Jama'ah al-Muslimin. Artinya sekelompok mayoritas terbesar di antara umat Islam. Lalu ketika ada persoalan yang berkembang di masyarakat, mereka selalu berserah diri kepada Allah dan mengharapkan pertolongan sesuatu kepada-Nya sebagai Zat Yang Maha Mengetahui.

Dengan demikian, secara bahasa terdapat dua pendapat yang menyebutkan asalusul nama aliran Murji'ah. Pendapat pertama, diambil dari akar kata arja- yurji- irja'murji (مرجية) yang artinya bermacam-macam, yaitu: (Syahrastani, n.d.). Pertama, Menunda (at-ta'khir) sama dengan Murji'ah dalam arti menunda (menangguhkan) maksudnya adalah bahwa dalam menghadapi sahabat-sahabat yang bertentangan, mereka tidak mengeluarkan pendapat siapa yang bersalah, tetapi menunda dan menangguhkan penyelesaian tersebut di hari akhirat dihadapan Allah SWT. Aliran ini disebut murjiah, karena menunda penyelesaian permasalahan antara Ali ibn Abi Thalib. Muawiyyah bin Abu Sufyan, dan kelompok Khawarij sampai di akhirat. Mereka 
menyatakan bahwa orang yang berdosa besar tetap mukmin selama masih beriman kepada Allah SWT dan Rasul-Nya. Sedangkan orang yang melakukan dosa besar di akhirat baru ditentukan hukumannya oleh Allah SWT. (Syahrastani, n.d.). Teori yang berkaitan dengan masalah teologi yang mengatakan bahwa gagasan irja' atau arja dikembangkan oleh sebagian sahabat dengan tujuan menjamin persatuan dan kesatuan umat Islam. Pada waktu itu terjadi pertikaian politik di antara beberapa kelompok, dengan menyerahkan segala persoalan kepada Allah untuk menghindari munculnya sektarianisme. Dengan demikian tidak terjadi perpecahan karena tidak ada yang paling benar. Pada teori ini Murji'ah diposisikan sebagai kelompok politik maupun teologis.

Kata murji'ah berasal dari kata; arja'a - yurji'u-irja', artinya mengembalikan menyerahkan, memasrahkan. Murji'ah dengan arti memberi harapan, maksudnya adalah bahwa orang-orang islam yang berbuat dosa besar tidak menyebabkan mereka menjadi kafir. Mereka tetap mukmin dan tetap mendapatkan rahmat Allah meskipun mereka harus masuk lebih dahulu dalam neraka karena perbuatan dosanya. Namun murji'ah diberikan untuk golongan ini karena mereka memberi pengharapan bagi orang yang berdosa besar untuk masuk surga. Teori kedua berkaitan dengan masalah politik, teori ini mengatakan bahwa gagasan irja' muncul pertama kali sebagai gerakan politik yang diperlihatkan oleh cucu Ali bin Abi Tholib yaitu Al-Hasan bin Muhammad AlHanafiyah sekitar tahun $695 \mathrm{M}$. Dengan gerakan politik tersebut Al-Hanafiyah mencoba menanggulangi perpecahan di kalangan umat Islam. Ia menolak berdampingan dengan kelompok Syi'ah yang terlampau mengagungkan Ali dan para pengikutnya. Juga berusaha menjauhkan diri dari kelompok Khawarij yang menolak kekhalifahan Muawiyah (Nuruddin, 2012).

Mengesampingkan (al-ilga'). Murji'ah dalam pengertian ini adalah golongan yang mengesampingkan terhadap amal perbuatan. Golongan ini menganggap yang terpenting dan iutama dalam agama adalah iman, bukan amal. Amal perbuatan hanya merupakan soal kedua, karena yang menentukan mukmin atau kekafiran seseorang adalah iman bukan perbuatan. Dengan demikian, iman lebih penting dibandinkan daripada amal perbuatan. Akibatnya, kelompok ini lebih pasif dalam berbuat dibanding kelompok lain.

Munculnya sekte Murji'ah di atas berlatar belakang dari persoalan politik, terutama tentang khilafah (suksesi). Dimulai sejak terbunuhnya khalifah Usman bin 
Affan, umat Islam terpecah ke dalam tiga kelompok, yaitu; golongan Khawarij, Syi‘ah dan Muawiyah. Dalam merebut kekuasaan kelompok Muawiyyah membentuk dinasti Umayyah. Melihat fenomena seperti ini kaum Syi'ah dan Khawarij berusaha menentang kekuasaan yang shah. Syi'ah menentang Muawiyyah karena duanggap telah merebut kekuasaan yang seharusnya hak bagi Ali dan keturunannya. Sementara golongan Khawarij tidak mendukung Muawiyyah karena ia dinilai menyimpang dari ajaran Islam. Dari persoalan politik llalu berkembang ke masalah agama.

Pertikaian antar golongan di kalangan para elit kekuasaan memunculkan sikap saling mengkafirkan (takfir) antara satu kelompok dengan kelompok lain. Akhirnya, muncul kelompok ketiga yang menyatakan diri tidak ingin terlibat dalam pertentangan politik yang sedang berlangsung. Kelompok inilah kemudian berkembang menjadi suatu golongan yang dinamakan kaum Murji'ah (Nuruddin, 2012).

Jadi, kehadiran aliran Murji'ah pada awalnya merupakan solusi untuk menghindari perpecahan umat pada waktu itu, terutama dalam menyelamatkan persatuan masyarakat dari keadaan cheosh. Karena tidak semua masyarakat mengetahui asal muasal konflik tersebut, mereka lebih menyukai perdamaian daripada peperangan yang telah lama terjadi. Untuk itu mereka memiliki komitmen mengedepankan aspek keyakinan daripada amal perbuatan. Menurut kelompok Murji'ah, walaupun seseorang telah melakukan dosa besar, selama masih meyakini tiada Tuhan selain Allah, maka ia tetap dianggap seorang mukmin bukan kafir. Akibatnya, muncul sikap pasif dalam menghadapi kehidupan sehari-hari, sehingga tidak nampak pengaruh keimanan dalam kehidupan sehari-hari. Namun dalam perkembangannya, aliran ini juga terbawa arus di masyarakat, mereka menjadi kelompok politik tertentu akibat tokohnya yang aktif dalam masalah tersebut.

Sebagaimana telah disebutkan, pada mulanya aliran Murji'ah itu berupa jama'ah muslimin yang belum tampil secara resmi sebagai aliran keagamaan maupun politik. Namun setelah terjadi gesekan politik yang sangat kuat di kalangan umat Islam, memaksa kelompok ini tampil menjadi sebuah aliran yang disebut Murjiah. Sebutlnya istilah ini datang dari lawan politiknya. Karena sikapnya tidak mau menyebut kafir terhadap seorang mukmin yang berbuat dosa besar sebelum bertaubat. Mereka menunda persoalan tersebut dengan menyerahkan kepada Allah SWT. 
Secara resmi aliran Murjiah berdiri pada akhir abad pertama hijriyah di wilayah Damaskus yang dipelopori oleh Hasan bin Bilal al-Muzni, Abu Salat as-Samman, Tasbit bin Quthananh, dan auban Dhiror bin Umar (Amin, 1961). Golongan ini dinamakan Murjiah, karena kelompok 'menunda' status hukum bagi seorang mukmin yang berbuat dosa besar dan belum bertaubat lalu ia meninggal apakah tetap mukmin atau dihukumi kafir. Mereka menyerahkan urusan tersebut sepenuhnya kepada Allah Swt Zat yang Maha Mengetahui (Hanafi, 2001, hal. 11). Dalam perkembangannya, aliran ini terbagi menjadi dua kelompok besar, yaitu kelompok moderat dan kelompok ekstrim. Kelompok moderat dipelopori oleh Hasan bin Ali bin Abu Talib dari generasi Sahabat, lalu dilanjutkan oleh Abu Hanifah (w. $150 \mathrm{H}$ ) dari genereasi Tabiin, dan diteruskan oleh Abu Yusuf dari generasi Tabiit Tabi'in. Akhirnya diperkuat oleh Imam Ahmad bin Hanbal (w. $241 \mathrm{H}$ ) tokoh hadis pada saat itu. Pada masa ini mereka tampil sebagai gerakan keagamaan yang berusaha menetralisir perpecahan umat akibat pertikaian antara aliran Khawarij dan Syi'ah yang saling mengkafirkan.

Adapun kelompok ekstrem berkembang sangat banyak menjadi tujuh macam sebagai aliran. Pertama, Yunusiyyah adalah salah satu sekte Murji'ah yang dipelopori oleh Yunus ibn 'Aun an-Numairy. Menurut kelompok ini pengertian iman adalah percaya kepada Allah dengan mentaati semua perintah-Nya, menyerahkan segala urusan kepada-Nya, mencintai Allah dengan sepenuh hati, bersikap rendah hati, dan tidak berbuat kufur. Adapun sifat kufur adalah kebalikan dari sifat-sifat itu (Syahrastani, n.d.). Dikatakan kafir bukan karena tidak percaya kepada Allah SWT., melainkan sikap ketakaburannya. Sebagaimana dsebutkan dalam firman Allah dalm QS. Al-Baqarah: 34 sebagai berikut;

Artinya: "Ia enggan dan bersikap takabur, karenanya termasuk golongan orang-orang kafir" (Al-Qur'an dan Terjemahnya; 6).

Menurut kelompok ini masih mengakui definisi iman adalah at-tashdiq wa alaf'al (meyakini dan melasanakan). Tetapi, keimanan seseorang tidak akan hilang akibat perbuatan yang buruk, seperti melakukan dosa besar. Sebagaimana dikemukakan oleh Yunus an-Numairy; "Barangsiapa yang menanamkan rasa kepatuhan hanya kepada Allah semata dan mencintai Allah dengan sepenuh hati, sekalipun ia melakukan kemaksiatan, maka perbuatannya tidak akan mengurangi nilai iman dan keikhlasan, 
karena menurut mereka perbuatan jahat dan maksiat tidak akan merusak iman seseorang (Islam, 2002).

Dari penjelasan di atas, nampak ciri khas ajaran Murji'ah, yaitu sifat ekstrem keimanan yang tidak mengakui adanya perubahan iman (yazid wa yanquș) akibat perbuatan dosa yang dilakukan. Padahal menurut jumhur konsep tentang iman sangat terkait dengan amal perbuatan. Sedangkan kelompok ini hanya kedudukan formal, sedangkan implikasinya terhadap kehidupan di dunia dikesampingkan.

Dalam melihat pemikiran Yunus an-Numairy tentang konsep iman dalam konteks kehidupan di masa sekarang harus didudukkan secara tepat, tidak eklusif. Bagi kaum awam atau mayoritas umat Islam yang dipentingkan adalah nilai formalitas, seperti KTP. Dengan adanya penegasan ini maka akan mudah mengetahui identitas seseorang. Hal ini akan akan mempermudah dalam membina kehidupan keagamaan mereka, sehingga tumbuh semangat religiositas yang tinggi. Pembinaan secara intensif baik menyangkut dimensi akidah, ibadah, muamalah, sosial, moral, dan tasawuf. Dari sini diharapkan akan tumbuh kesadaran sebagai seorang mukmin sejati (kaffah) atau tumbuh keimanan yang produktif. Dengan demikian sikap dasar yang mereka miliki yaitu mencintai Allah dengan sepenuh hati, iman sifatnya tetap walaupun berbuat maksiat, dan dijamin masuk syurga akan terjadi perubahan.

'Ubaidiyyah Kelompok ini dipelopori oleh 'Ubaid al-Mukatib, menurutnya semua dosa yang dilakukan seseorang selain berbuat syirik pasti diampuni oleh Allah SWT. Apabila seseorang meninggal dunia dalam keadaan mengesakan Allah (muwahhid) bagi mereka tidak ada dosa yang telah dilakukan atau kejahatan yang menghancurkan terhadap keimanannya. Menurut kelompok 'Ubaidiyah, seseorang yang meninggal dalam keadaan masih memiliki ketauhidan tidak akan merugikannya, meskipun ia berbuat fasik. Sebab, perbuatan jahat yang dilakukan tidak akan merusak keimanannya. Begitupun sebaliknya, perbuatan baik yang dilakukan oleh orang-orang kafir tidak akan memperbaiki posisi orang tersebut di akhirat. Mereka pasti akan sengsara karena yang menentukan keberuntungan seseorang adalah keimanan, bukan yang lain (Saeed, 2014) 
Ghassaniyyah Kelompok ini dinamakan golongan al-Ghassaniyyah karena mengikuti ajaran yang dikembangkan oleh Ghassan al-Kafi. Menurut pemikiran Ghassan al-Kafi, iman adalah pengetahuan (al-ma'rifah) kepada Allah dan Rasul-Nya. Jika seseorang mengatakan bahwa saya tahu Tuhan melarang makan babi, tetapi saya tidak tahu apakah babi yang diharamkan itu adalah kambing ini, orang yang demikian tetap mukmin, bukan kafir. Dan jika seseorang mengatakan, saya tahu Tuhan mewajibkan naik haji ke Ka'bah tetapi saya tidak tahu apakah Ka'bah terletak di India atau tempat lain, orang demikian juga tetap mukmin. Artinya, keyakinan-kayakinan tentang penjabaran keimanan berada di luar persoalan iman, dan tidak ada hubungannya dengan keimanan (Imarah, 1991). Jadi orang-orang tersebut pada dasarnya tidak meragukan hal-hal tersebut di atas, karena setiap orang yang berakal pasti tidak meragukan letak ka'bah. mengetahui perbedaan antara kambing dan babi. hanya saja pelaksanaannya terhadap perintah dan larangan Allah belum terwujud, tetapi tidak mempengaruhi keiamnannya. Yang membedakan antara kelompok Ghassaniyyah dengan kelompok lain adalah terletak pada konsekwensi terhadap perintah dan larangan yang dilanggar. Kelompok ini tidak mengakui eksistensi seorang munafik, mereka hanya membagi varian keimanan sesorang menjadi dua macam; yaitu mukmin dan kafir. Ekstremitas kaum Ghassaniyah terletak pada peniadaan sifat munafik, padahal term ini sangat membahayakan dampaknya bagi keimanan seseorang mmaupun masyarakat muslim sebagaimana ditegaskan dalam al-Qur'an. Oleh karenanya al-Qur'an mengingatkan umat Islam terhadap sifat kepura-puraan dalam beragama.

Saubaniyyah Saubaniyyah dipelopori oleh Abu Sauban, ia berpendapat bahwa iman adalah pengenalan dan pengakuan lidah kepada Allah, mengetahui dan mengakui sesuatu yang menurut akal wajib dikerjakan. Singkatnya mengakui adanya kewajibankewajiban yang dapat diketahui akal sebelum datangnya syari'at. Allah SWT. akan mengampuni seorang pendosa pada hari kiamat asalkan tetap beriman yang berada pada posisi yang sama (Zahroh, 1996). Jadi antara tashdiq, taqrir, dan af'al (perbuatan) sudah ada pada diri kelompok ini, hanya saja perbuatan yang dilakukan seseorang tidak mempengaruhi terhadap status keimanannya. Oleh karenanya, kurang memacu semangat beramal dalam kehidupan. Sebab, lebih mementingkan dimensi keyakinan saja, juga sebatas status formaldalam kehidupan. 
Salihiyyah sekte Salihiyyah diambil dari nama tokohnya Al-Salihy ibn Umar AlSalihy. Menurut paham ini, iman adalah semata-mata mengenal Allah sebagai Sang Pencipta, sedangkan kufur adalah ketidaktahuan terhadap eksistensi Allah. Amal perbuatan seperti salat bukanlah ibadah, kecuali dari orang yang beriman kepada-Nya, karena ia telah mengenal-Nya. Iman meliputi pengenalan kepaa Allah SWT. Ini merupakan kualitas yang tidak terbagi, yang tidak bertambah dan berkurang, demikian juga kekafiran merupakan kualitas yang tidak terbagi, yang tidak bertambah dan tidak berkurang (Jamrah, 2015).

Sekte Marisiyyah dipelopori oleh Bisyar al- Marisy. Paham ini meyakini bahwa pengertian iman adalah meyakini dalam hati bahwa tiada Tuhan selain Allah dan Nabi Muhammad Rasul-Nya, juga harus diucapkan secara lisan. Jadi, ukuran keimanan terkait dengan tashidiq dan taqrir (Jamrah, 2015). Maka tidak dikatakan iman jika tidak diyakini dalam hati dan diucapkan secara lisan. Kelompok ini lebih modern daripada lainnya, karena memahami iman tidak sebatas keyakinan saja, tetapi juga pengakuan secara lesan. Meskipun demikian, bagi mereka perbuatan bukanlah menjadi ukuran keimanan, sama dengan kelompok Murji'ah lainnya. Salah satu ciri utama aliran Murji'ah adalah penetapan keimanan yang didasarkan pada keyakinan saja, tidak sampai pada perbuatan karena mereka menganggap bahwa hidaya itu datangnya dari Allah sehingga tidak mungkin hilang dari dada seseorang. Nmaun bagi kelompok ini sedikit lebih moderat, karena mereka juga menekankan pada ucapan, sehingga dapat diketahui orang lain, meskipun sifatnya formal. Sehingga tingkat ektremitasnya tidak terlalu keras, dibanding kelomok lain.

Pendukung paham Karamiyyah adalah Muhammad bin Karram. Salah satu aliran yang terakhir dari kaum Murji'ah. Pendapat ini berpendirian bahwa iman adalah pengakuan secara lisan dan kufur adalah pengingkaran secara lisan pula. Status mukmin dan kafir pada seseorang dapat diketahui melalui pengakuannya secara lisan (Nasution, 2011). Sebagai aliran yang berdiri sendiri, kelompok Murji'ah ekstrem sudah tidak didapati lagi sekarang, walaupun demikian, ajaran-ajarannya dan pengaruhpengaruhnya masih didapati pada sebagian umat Islam. Adapun ajaran-ajaran dari kelompok Murjiah moderat, terutama mengenai pelaku dosa besar serta pengertian iman dan kufur, menjadi ajaran yang umum disepakati oleh umat Islam. 


\section{Beberapa Doktrin Murji'ah}

Suatu aliran atau sekte tidak terlepas dari ajaran tertentu yang diyakini sebagai sebuah kebenaran, Meskipun di mata kelompok lain pahamnya termasuk bid'ah, namun di kalangan pendukungnya dianggap sebagai sebuah kebenaran. Selama keyakinan itu tidak menganggap dirinya kelompok yang paling benar di hadapan paham lain, Akan tetapi jika telah mengklaim dirinya sebagai satu-satunya paham yang paling benar, menghina aliran lain. Sikap seperti ini termasuk kategori ajaran yang sesat dan tidak bisa diikuti. Politik (as-siyasah), istilah politik di sini lebih tepat dikaitkan dengan makna khilafah, yaitu menyangkut bai'ah terhadap penguasa. Doktrin-doktrin politik sebagai implikasi dari doktrin yang dilakukan oleh segolongan sahabat Nabi terhadap paristiwa pertikaian di Madinah yang membawa terbunuhya Usman bin Affan sangat beragam. Menanggapi kajadian seperti ini kaum Murji'ah mengambil sikap tidak mau melibatkan diri dalam perselisihan politik, begitu juga ketika terjadi kasus arbitrase, mereka bersikap netral. Kemudian ketika sudah muncul pemerintahan yang baru, sikap ba'ah dilakukan terhadap pemimpin yang terpilih dengan maksud agar terwujud kedamaian di masyarakat (Amin, 1961). Sebagaimana disebutkan pada halaman sebelumnya, bahwa kesepakatan damai itu merupakan indikasi karakeristik mereka dengan sikap menahan diri untuk memberikan penilaian dan menyerahkannya melalui kehendak Tuhan. Artinya, setelah terjadi keputusan, maka persoalan selanjutnya dikembalikan kepada Allah SWT., Sikap ini mencerminkan nilai yang terkandung dalam al-Qur'an yaitu meyerahkan diri kepada Allah.

Political will yang dilakukan kelompok Murji'ah yaitu bersikap netral, menjadikan mereka dapat diterima oleh semua pihak. Dengan prinsip seperti ini pula, nampak golongan Murji'ah mengakui keabsahan khalifah Usman, Umar, Ali, maupun Mu'awiyah. Sebab, mereka masih seorang muslim, wajib ditaati. Sikap seperti ini diikuti oleh kelompok jama'ah yang menjadi embrio paham Ahl as-Sunnah wa al-Jama'ah di masa berikuttnya. Lembaga khilafah disebut juga ad-daulah (negara) menurut kaum Murji'ah bukanlah suatu kewajiban, mereka berpendapat sama dengan apa yang dikemukakan kelompok Khawarij. Namun jika kekhalifahan sudah terbentuk, seharusnya ditegakkan seorang pemimpin (al-Imam). Menurut mereka imam yang terpilih itu adalah orang yang mampu dan tidak disyaratkan berdarah Quraisy (Zahroh, 
1996). Dari keterangan di atas tampak nilai demokrasi yang dilakukan oleh para pengikut Murji'ah dalam mensikapi permasalahan khilafah; Satu sikap yang mencerminkan nilai-njlai al-Qur'an dan Sunnah Nabi.

Sebagaimana disebutkan dalam QS. Al-Hujurat ayat 12 tentang perintah bersatu dalam suatu masyarakat dan larangan bercerai berai (firqah). Sikap seperti ini dilakukan ketika kondisi sedang kacau, sebagaimana dilakukan golongan Murji'ah. Namun manfaatnya sangat besar terhadap keutuhan sebuah negara atau pemerintahan. Oleh karenanya ajaran yang mereka tanamkan perlu dipupuk oleh segenap umat Islam dewasa ini, sebagaiamana yang sedang dilanda konfliks. Hukum orang berdosa besar (murtakib al-kabair). Persoalan takfir, yaitu pengkafiran terhadap kelompok lain sering muncul di tengah masyarakat, bahkan pemicunya terkadang sepele, padahal masalah ini merupakan sesuatu yang besar. Oleh karena akan memunculkan terjadinya konfliks di kalangan umat Islam. Sebagaimana golongan lain, kaum Murji'ah banyk berdomisiil di ibu kota mempunyai pendirian bahwa orang yang berdosa besar tidak kekal di neraka dan orang telah melakukan dosa besar seberapaun banyaknya tidak akan menjadi kafir (Zahroh, 1996).

Persepsi ini muncul sebagai antitesa terhadap kelompok lain tentang capital sinners (orang yang berbuat dosa besar) dipandang sebagai orang kafir. Kaum Murji'ah menolak asumsi pelaku dosa besar adalah kafir, atau termasuk kelompok fasiq. Menurutnya, mereka tetap tergolong orang Islam yang sedang berbuat dosa; baik, eksistensinya masih mukmin, dan ada kemungkinan masuk syurga. Adapun balasan neraka tetap akan dikenakan sebagai konsekwensi logis atas perbuatan dosanya. Hanya saja, mereka akan masuk syurga, sedang persoalan waktunya, sepenuhnya diserahkan kepada kehendak mutlak Tahun (Syahrastani, n.d.). Menurut Murji'ah, keimananan sifatnya tetap, tidak hilang dari hati, tetapi akan senantiasa berubah tergantung amal perbuatannya. Bagi orang yang beriman tetapi melakukan maksiat dosa besar (murtakib al-kabair), imannya tidaklah hilang dari dirinya, karena kemungkinan akan diampuni atau sebaliknya, tergantung pada Alllah. Meskipun akan disiksa pada akhirnya ia akan dimasukkan ke syurga (Syahrastani, n.d.). 
Argumen yang dipakai Murji'ah adalah ayat dan hadis Nabi sebagai berikut; Pertama, ayat 53 QS. az-Zumar sebagai berikut,

Artinya: "Katakanlah wahai hamba-hamba-Ku yang melanggar batas sehingga merugikan diri sendiri, janganlah berputus asa atas rahmat Allah, Sesungguhnya Allah mengampuni segala dosa, karena Ia Maha Pengampun dan Maha Bijaksana. (Al-Qur'an dan Terjemahnya:1999, 371).

Kedua, QS. an-Nisa' ayat 48, berbunyi sebagai berikut;

Artinya: "Allah tidak akan mengampuni dosa seseorang, melainkan perbuatan syirik terhadap diri-Nya, Barang siapa yang berbuat syirik terhadap Allah sungguh ia telah melakukan dosa yang sangat besar ).

Ayat di atas menandung makna bahwa semua dosa manusia akan diampuni oleh Allah Swt, kecuali berbuat syirik. Dengan demikian setiap orang beriman akan dijamin masuk syurga meskipun pernah melakukan dosa besar.

Ketiga, sebuah hadis Nabi yang diriwayatkan Ibn Majah berbunyi sebagai berikut:

Artinya: "Akan dikeluarkan dari siksa api neraka seseorang yang mengucapkan Lailaha illallah, sedangkan dalam hatinya terdapat kebaikan meskipun sebesar biji sawi" (HR Ibn Majah).

Makna hadis di atas menerangkan bahwa semua orang yang meninggal dalam keadaan beriman ia akan mendapat pahala di syurga, setelah dimasukkan ke neraka.

Jadi, ajaran Murji'ah tentang dosa besar tidak bertentangan dengan ayat al-Qur'an dan Sunnah Nabi. Karena masalah keakhiratan (eskatologi) adalah perkara yang hanya diketahui Allah semata, maka dasar penetapannya harus memakai dalil naqli. Sebab tak satupun makhluknya mengetahui secara pasti tentang hal ini, sifatnya supra rasional (di luar wilayah akal). Hal ini tidak terjangkau akal budi manusia dikarenakan keterbatasan ilmu yang dimiliki disebutkan dalam QS. Al-Isra' ayat 85 yang berbunyi sebagai berikut:

Artinya; "Dan kamu tidak diberi ilmu (keakhiratan) kecuali sangat sedikit."

Kandungan ayat di atas menjelaskan tentang kelemahan peran akal mengeai masalah keimanan. Oleh karenanya kepercayaan Murji'ah di atas menjadi inspirasi terhadap corak teologi yang berkembang pada masa berikutnya, terutama aliran Ahl as- 
Sunnah wa al-Jama'ah yang dipelopori oleh Abu Hasan al-Asy'ary. Terutama golongan moderat, sebab pembangun utama (the founding father) golongan ini pada hakekatnya adalah tokoh-tokoh pembangun Aswaja, seperti Imam Hanafi. Ahmad bin Hanbal, asSyafi'i, dan Imam Malik.

\section{Konsep Iman (al-iman)}

Salah satu ciri suatu aliran adalah penekanan pada bidang tertentu yang membedakan dengan aliran lainnya. Misalnya, Mu'tazilah memiliki keyakinan pada alUsul al-Khamsah (lima dasar ajaran), Syi'ah terkenal dengan ajaran al-Imamah (kepemimpinan), Khawarij terkenal dengan ajaran takfir (pengkafiran), dan Murjiah adalah tentang tahdid ma'naal-iIman (batasan tentang keimanan). Menurut Murjiah, penetapan keimanan seseorang sangat sederhana, cukup dengan pembenaran dalam hati (tasdiq fi al-qalb). Dengan istilah lain mengenal Allah cukup dalam hati, tidak harus dibarengi dengan ucapan (taqrir), apalagi juga perbuatan (af'al). Konsekwensinya, seseorang yang telah beriman dalam hati, berarti sudah dikatakan mukmin atau muslim (Nasution, 2011). Dengan demikian sangat mudah membedakan antara orang mukmin dan kafir. Argumentasi yang dibangun untuk membedakan antara iman dan kafir adalah dengan pendekatan bahasa (qa'idah lughawiyyah). Mereka menyatakan bahwa iman dalam pengertian bahasa adalah membenarkan saja bukan yang lain. Amal perbuatan merupakan masalah tersendiri, yaitu tentang amal salih. Jadi model pemahaman keimanan terfokus pada level kulit (manhaj az-zahiry), yaitu dimensi eksoteris (makna tekstual). Sebab hal ini tidak terlepas dari para pengikutnya yang mayoritas terdiri dari kaum awam yang tidak memerlukan penjelasan secara filosofis.

Selanjutnya, iman menurut mereka mempunyai dua rukun, pertama membenarkan dalam hati dan kedua mengikrarkan dengan lisan. Kedua rukun ini harus terpenuhi supaya dikatakan beriman. Pembenaran dengan hati saja tidak cukup, atau dengan ikrar lisan saja juga tidak cukup, tetapi mesti dilakukan serentak antara keduanya. Sedangkan rukun yang ketiga, yaitu mengamalkan dengan perbuatan bukanlah merupakan rukun iman. 


\section{Dasar Keselamatan (as-salamah)}

Dasar pokok keselamatan adalah hanya iman, selama masih ada iman, setiap bentuk kemaksiatan tidak dapat mendatangkan madharat atau gangguan terhadap seseorang. Untuk mendatangkan pengampunan, cukup dengan menjauhkan diri dari perbuatan syirik dan mati kafir. Dengan kata lain, kelompok Murji'ah memandang perbuatan atau amal tidak sepenting iman,. Sedangkan iman terletak dalam hati dan tidak diketahui oleh orang lain. Sedangkan amal perbuatan tidak menggambarkan apa yang ada dalam hati. Oleh karena itu ucapan dan perbuatan seseorang tidak mengandung arti bahwa ia tidak memiliki iman. Adapun bagi seseorang yang lalai menunaikan ibadah atau terjerumus melakukan dosa-dosa besar, menurut tokoh Murji'ah tidaklah mungkin menentukan hokum bagi orang itu di dunia ini. Hal itu haruslah ditangguhkan kepada Tuhan untuk menentukan nasibnya di hari kiamat. Dari sini timbulnya istilah "Murji'ah" (Saeed, 2014).

Pengikut Murjiah sangat mengagungkan keyakinan atau iman dan menomorduakan amal perbuatan. Karena, kemaksiatan yang dilakukan seorang tidak dapat mempengaruhi kualitas imannya, sebagaimana tidak berfungsinya ketaatan orang kafir. Maka derajad iman lebih tibnggi dan tidak dapat disamakan dengan amal. Kemudian dijelaskan bahwa amal perbuatan tidak memegang peranan terhadap keyakinan, karena iman seseorang tidak akan rusak oleh dosa yang diperbuat. Oleh karena itu, kaum Murjiah berpendapat bahwa amal perbuatan seseorang tidak dapat dipakai sebagai ukuran dalam menentukan keislaman atau kekafiran seseorang, selain iman dalam hati. Melihat bentuk pemikiran, seolah-olah mereka telah memisahkan antara konsep iman dan amal. Padahal keadaan ini tidak sesuaia dengan ayat dan hadis Nabi. Memang, jika dilihat dari proses tahapan iman yang paling rendah adalah keyakinan terhadap Allah sebagai Zat Pencipta alam semesta.Pada tahapan ini seseorang belum mampu mengkombinasikan antara iman dan Islam. Tahapan ini disebut keimanan orang awam. Tingkatan kedua, iman seorang khawash, yaitu keimanan yang dimiliki seseorang telah mampu menjalankan amal salih. Ketiga, tingkatan keimanan syaksh al-khawash, yaitu keimanan yang telah mampu menghayati makna keyakinan dan amal salih yang diimplementasikan dalam kehidupan sehari-hari. 
Para ulama kalam berkeyakinan bahwa iman akan bertambah atau sebaliknya. Iman tidak bertambah dan tidak berkurang karena amal perbuatan sebagaimana dikemukakan kelompok Murji'ah penulis kurang sepakat, sebab pada hakekatnya keimanan yang tetap masih berupa potensi, bukan materi. Secara potensi, setiap manusia dilahirkan telah beriman, hanya saja perkembangannya bergantung pada proses pendidikan di masa mendatang. Jika pendidikannya mengarah pada ajaran Islam, maka ia akan menjadi seorang beriman atau sebaliknya. Disinilah letak perbedaan antara potensi dan materi iman.

\section{Toleransi (at-tasamukh)}

Toleransi adalah sikap menghargai pendapat orang lain yang berbeda dengan diri sendiri, tidak merasa pendapatya paling tepat, serta tidak memaksakan kehendak kepada orang lain. Sifat ini muncul akibat dari konsep penundaan dan penyerahan tentang status orang yang berbuat dosa besar. Bagi kaum Murji'ah seorang pelaku dosa besar apakah dihukumi mtentang mukmin atau kafir ternyata membawa konseukmin atau kafir adalah urusan Allah, bukan wewenang manusia, karena menyangkut banyak hal. Pertama, terdapat dalil yang ta'arudh (bertentangan), sehingga memerlukan ijtihad untuk menetapkannya. Untuk itu hasilnya pun tidak dapat diklaim seseorang. Dengan kata lain ayatnya bersifat zanny (samar).

Kedua, masalah pertikaian yang terjadi di masyarakat tentang hukum pelaku dosa besar ternyata menimbulkan dampak besar terhadap kelangsungan perdamaian umat Islam, untuk itu diperlukan bentuk pemahaman yang dapat menyejukkan dan menjaga ukhuwah Islamiyah. Salah satu jalan yang mesti ditempuh adalah menerima perbedaan pendapat yang ada dengan tidak memojokkan salah satunya. Sikap inilah yang ditempuh kelompok Murji'ah moderat. Mereka mampu menjembatani perbedaan antara kelompok Khawarij dan Syi'ah sebagai kelompok Jama'ah. Sehingga kehadirannya menjadi tumpuan masyarakat umum pada waktu itu. 


\section{Latar belakang Kemunculan Murjiah}

Setelah melihat sejarah perkembangan Murjiah di atas, kehadiran kelompok ini merupakan solusi yang tepat dalam mengatasi persoalan yang muncul pada waktu itu. Pertikaian antara golongan Khawarij, Syi'ah dan Muawiyah dalam meraih kekuasaan menumbulkan permusuhan yang mendalam. Maka diperlukan kelompok baru yang mampu menghindari konfliks, sebab pada umumnya masyarakat muslim tidak masuk ke dalam kelompok yang bertikai, tetapi mereka mengalami kebuntuan akibat tarikan politik yang kuat, Kehadiran kelompok Murjiah mampu 'mewadahi' massa, terutama yang enggan bertikai. Munculnya golongan Murji'ah pada dasarnya merupakan antitesa terhadap keberadaan dari kaum Syi'ah dan Khawarij yang secara garis besar membicarakan tentang khilafah (politik), kekufuran, dan masalah keimanan. Karena merupakan antitesa, maka ajaran-ajaran pokoknya juga berkisar pada hal-hal yang sudah berkembang,seperti tentang keimanan, pengkafiran, dosa besar, dan pemerintahan (Amin, 1961).

Kehadiran kelompok Murji'ah sangat menyejukkan umat Islam, karena tidak mau mengkafirkan salah satu golongan Suatu misal, kaum Khawarij yang menganggap kelompok Syi'ah telah berbuat kafir karena tidak menegakkan hukuman berdasarkan alQur'an. Sedangkan kaum Syi'ah menuduh kelompok Khawarij juga telah kafir karena firqah (terpecah dari jama'ah) yaitu keluar dari barisan Syi'ah. Sedangkan pendukung Muawyah juga mengatakan kedua kelompok tersebut telah berbuat firqah dari jama'ah. Menanggapi perbedaan politik tersebut kelompok Mu'awiyyah berpendapat bahwa demi menjaga persaytuan umat Islam yang sangat besar jumlah maupun wilayahnya diperlukan kedamaian, kesejukan, dan toleransi. Maka mereka mnerima pemerintahan Muawiyyah sebab secara riil sudah berjalan. Sedangkan dalam masalah akidah menyerahkan status hukumnya kepada Allah SWT., sehingga tidak terjadi pertikaian di antara umat Islam.

Adapun terkait dengan perpecahan kelompok Murjiah menjadi dua macam, yaitu modeat dan ekstrim hal ini disebabkan oleh jumlah massa yang besar pasti akan terjadi perbedaan pendapat di kalangan mereka. Ada kelompok yang ingin menonjol di masyarakat tetapi mereka tidak memahami secara mendalam terhadap kandungan ajaran 
Islam. Untuk itu mereka membuat ajaran yang berbeda dengan pakem yang berkembang. Mereka itulah kelompok garis keras.

Sebagaimana dikatakan Harun Nasution, pakar teologi Islam di abad XX, setelah berkembang di kalangan masyarakat menengah ke bawah, kelompok Murji'ah terpecah menjadi dua golongan besar, yaitu kelompok moderat dan kelompok ekstrem. Golongan moderat adalah kelompok yang berpegang pada pendapat ulama Salaf, seperti Imam Hanafi dan Imam Ahmad, Hasan bin Muhammad bin Ali bin Abi Thalib, Abu Hanifah, Abu Yusuf, dan beberapa ahli hadis. Kelompok moderat adalah kelompok yang teguh berpegang pada doktrin Murji'ah awal seperti yang telah dijelaskan di atas, yaitu pelaku dosa besar tetap beriman, tetapi fasiq, dan akan mendapatkan syafat'at karena keimanannya. Sedangkan kelompok Murji'ah ekstrem adalah golongan Murji'ah yang telah terpengaruh oleh persoalan politik yang berkembang. Untuk mendapat simpati mereka mengajarkan keimanan secara esoteris semata.

\section{Ajaran tentang Keimanan minimalis (aqal al-iman)}

Keimanan yang diyakini aliran Murjiah hanya pada level pertama, yaitu keyakinan. Sebagai modaal awal dalam beragama sangat diperlukan, namun, sifat ini perlu dibina terus menerus agar terwujud keberagaman yang produktif, yaitu menginmplementasikan nilai-nilai ajaran Islam dalam kehidupan modern. Sebab, konsep keimanan yang bersifat esoteris sangat diperlukan pada zaman sekarang, tidak sekedar eksoteris saja. Sebagaimana dikemukakan oleh Imam Abu Hasan al-Asy'ari bahwa bangunan iman ada tiga macam, yatu; at-tasdiq (keyakinan), at-taqrir (ucapan), dan diamalkan dengan anggota badan (amal bil-jawarih]). Bangunan iman yang ideal ini selaras dengan isi QS. Al-'As|r ayat 3 yang berbunyi sebagai berikut;

Artinya: "Demi waktu. Sesungguhnya manusia sangat merugi. Kecuali orangorang yang beriman dan beramal saleh"

Bangunan keimanan yang hanya mengandalkan pada ucapan dan keyakinan akan kering dari amal salih yang bermanfaat bagi masyarakat modern. Model keimanan seperti belum mampu menghasilkan nilai produktifitas yang berguna bagi kehidupan. Di samping itu bentuk seperti ini rawan terjadi reduksi, yang menyebabkan terjadi lkonfersi agama. Karena keimanan sifatnya fluktuatif. Maka dari itu perlu dipupuk dengan amal salih, setelah tumbuh keyakinan. Hanya saja bagi masyarakat awam, seperti pada pengikut Murji'ah ragam keimanan seperti ini harus diterima sebagai 
bagian dari jelompok umat Islam, lalu disertai dengan pembinaan terus menerus tanpa ada kesudahan agar tertanam keimanan yang kuat.

\section{Ajaran tentang toleransi (at-tasamukh)}

Arti kata tasamukh menurut kamus Bahasa Indonesia adalah batas ukur, untuk penambahan atau pengurangan yang masih diperbolehkan. Sedangkan menurut istilah yang berkembang adalah sikap saling menghormati dan berlapang dada terhadap pemeluk agama lain, tidak memaksa mereka mengikuti agamanya dan tidak mencampuri urusan agama masing-masing.

Umat Islam diperbolehkan bekerjasama dengan pemeluk agama lain dalam aspek ekonomi, sosial dan urusan duniawi lainnya. Dalam sejarah, Nabi Muhammad Saw., telah memberi teladan mengenai bagaimana hidup bersama dalam keberagaman. Demikian juga seorang Sahabat Nabi Abdullah ibn Amr, dia telah menyembelih seekor kambing. Lalu berkata, “Apakah kalian sudah memberikan hadiah (daging sembelihan) kepada tetanggaku yang beragama Yahudi? Karena aku mendengar Rasulullah berkata, "Malaikat Jibril senantiasa berwasiat kepadaku tentang tetangga, sampai aku menyangka beliau akan mewariskannya kepadaku. (Dawud, 1989).

Contoh lain tentang masalah toleransi adalah penghormatan jenazah non muslim yang dilakukan Nabi. Ketika ada serombongan orang membawa jenazah melintas di depan Rasulullah, maka beliau berdiri. Para Sahabat bertanya, "Sesungguhnya ia adalah jenazah orang Yahudi wahai Nabi? Beliau menjawab, "Bukankah dia juga jiwa (manusia)? (Bukhari, n.d.).

Kemudian dalam bidang ekonomi, dalam sebuah riwayat diceritakan tentang masalah pinjam - meminjam (ariyyah), sesungguhnya Nabi Muhammad pernah berhutang makanan dari seorang Yahudi dan beliau menggadaikan pakian besi kepadanya. (Bukhari, n.d.).

Kebiasaan Nabi dan para Sahabat dalam menghargai pendapat orang lain diikuti oleh kaum Murji'ah, terutama dalam hal klaim pelaku dosa besar apakah tetap mukmin atau kafir. Bagi kaum kelompok ini tidak mau mengkafirkan aliran lain dan selalu menghargai perbedaan keyakinan. Mereka selalu mengedepankan toleransi dengan tidak mengangap kelompoknya lebih benar dan meyalahkan kelompok lain yang tidak sama pendapatnya. Diantara ajaran Murji'ah yang berpengaruh kuat di masyarakat modern adalah sikap toleransi (at-tasamukh). Ada beberapa sikap toleransi yang ditampilkan oleh kaum Murjiah, yaitu; pertama, Menghargai perbedaan pendapat 
dengan aliran lain terutama tentang hukum pelaku dosa besar (great sinner). Kedua, mau berbai'at terhadap pemimpin yang shah, yaitu pemerintahan Muawiyah bin Abu Sufyan sebagai khalifah shah setelah Ali bin Abu Talib. Hal ini didasarkan pada kenyataan bahwa mereka telah memerintah kaum muslimin, meskipun pada mulanya diperoleh dengan cara yang tidak demokratis.

Ketiga, Ukhuwah Islamiyyah. Prinsip ukhuwah sesama muslim menjadi landasan utama bagi golongan Murji'ah dalam menerima perbedaan politik dan keyakinan yang ada. Sebab, jika perbedaan tersebut berlarut-larut tanpa adanya titik kejelasan, maka akan menghilangkan semangat ukhuwah dan pada akhirnya menjadi ancaman terhadap masa depan umat. Keempat, pengaruh Ajaran at-tasamukh di masa Modern. Menurut para filosof Barat modern, salah satu ciri masyarakat modern adalah terbuka, egaliter, individu, dan rasional. Istilah modern berasal dari bahasa Latin "modo" = cara dan "ernus" = masa kini. Sebagaimana dikatakan oleh Talcott Parson bahwa ciri masyarakat modern adalah sebagai berikut: Netralitas efektif yaitu bersikap netral, bahkan dapat menuju sikap tidak memperhatikan lingkungan; Orientasi diri yaitu lebih mengutamakan kepentingan diri sendiri; Universalisme yaitu menerima segala sesuatu dengan obyektif; Prestasi yaitu suka mengejar prestasi; Spesifitas yaitu berterus terang dalam mengungkapkan segala sesuatu. Jadi, untuk menjadi masyarakat modern yang mampu berinteraksi dengan orang lain masih diperlukan satu sikap di luar keempat sifat tersebut, sebab ketika berinteraksi dengan orang lain tidak mungkin mengutamakan diri sendiri. Apalagi memakasakan kehendak. Dalam kondisi seperti ini dibutuhkan sikap demokratis, sebagai salah satu konsep keimanan yang dipakai oleh kaum Murji'ah. Dengan demikian pentingnya pengaruh ajaran Murjiah dalam kehidupan modern sangat besar. Sifat eksoteris sangat tepat dipakai dalam era posmodernisme. Sikap ini hanya akan tumbuh pada diri seseorang jika di dalam dirinya tumbuh sifat in group (inklusif). Pada umumnya dimiliki oleh kalangan masyarakat awam.

\section{Pentingnya menanamlam sikap Demokratis melalui Agama}

Sikap hidup demokratis merupakan sebuah sikap yang sangat berguna dalam kehidupa modern, apalagi setiap individu memeiliki watak dan kepribadian yang berbeda. Oleh karenanya menerima kehadiran orang lain secara total baik karena adanya kesamaan maupun perbedaan paham, keyakinan, aliran, atau kelompok politik 
mutlak diperlukan agar tetap terjaga kehidupan yang penuh persaudaraan dan persatuan. Sikap ini merupakan salah satu modal besar yang diperlukan dalam membangun bangsa dan negara di era global. Tanpa dasar ini suatu bangsa sulit mencapai kemajuan. Oleh karena nilai demookratis yang ditampilkan para tokoh dan pengikut kaum Murjiah pada zaman dulu perlu diteruskan serta diikuti umat islam pada masa sekarang.

\section{Menghindari perpecahan umat Islam}

Setiap orang sudah sepatutnya untuk menanamkan di dalam dirinya sifat toleran, serta menerapkannya di dalam kehidupan bersosial masyarakat, terutama di daerah yang di dalamnya terdapat berbagai jenis kepercayaan atau agama. Sikap toleransi antar umat beragama merupakan salah satu solusi untuk mengatasi terjadinya perpecahan di antara umat dalam mengamalkan agamanya. Sebagai contoh sikap toleransi antar umat beragama bisa kita lihat di negara kita ini, yaitu Indonesia yang memiliki lebih dari satu agama dan kepercayaan (Said, 2013). Jika toleransi antar umat beragama tidak tertanam di dalam pribadi masing-masing warga negara Indonesia, maka kemungkinan besar negara ini akan terpecah belah dan tidak akan bertahan lama.

\section{Mempererat silaturrahim}

Manfaat toleransi antar umat beragama berikutnya adalah terjalinnya tali silaturahmi. Pada umumnya, adanya suatu perbedaan selalu menjadi alasan terjadinya pertentangan antara orang (golongan) yang satu dengan lainnya, khususnya bagi mereka yang tidak bisa menerima adanya perbedaan tersebut. Salah satu contoh adalah adanya perbedaan agama yang menjadi salah satu faktor penyebab terjadinya berbagai konflik serta pertikaian di antara sesama manusia, seperti tindakan terorisme, pembantaian pemuka agama, dan lain sebagainya yang pada akhirnya akan mengakibatkan dampak pada timbulnya kesengsaraan bagi manusia lainnya. Lalu bagaimanakah solusi agar itu semua dapat dihindari? Solusinya adalah menumbuhkan kesadaran dalam diri masing-masing orang tentang pentingnya rasa saling menghormati dan menghargai guna merajut hubungan damai antar penganut agama. Dan jika hubungan damai telah terwujud maka tali silaturahmi antar pemeluk agama pun dapat terjalin dengan baik, bahkan lebih erat. Jika sudah begitu maka cita-cita 
bangsa untuk mewujudkan persatuan dan kesatuan di tengah-tengah banyaknya perbedaan akan dapat terwujud, dan itu akan menjadikan sebuah negara yang lebih kuat dan kokoh dalam menghadapi ancaman apapun (Ruslan, 2015).

Faktor keamanan, ketertiban, persatuan dan kesatuan dari sebuah negara merupakan salah satu kunci sukses menuju keberhasilan program-program pembangunan yang dicanangkan oleh pemerintahan di negara tersebut. Terjadinya kerusuhan, pertikaian, dan segala bentuk bencana baik bencana alam maupun bencana akibat ulah manusia menjadi salah satu hal yang harus diperhatikan oleh pemerintah. Kehidupan masyarakat yang meskipun di dalamnya terdapat berbagai perbedaan seperti perbedaan beragama akan tetapi ada sikap saling toleransi yang tertanam di dalam hati warga masyarakat tersebut, maka tentunya hal itu akan menciptakan suasana yang aman, tentram, dan damai di dalam lingkungan tersebut. Tidak akan ada sikap saling mengejek, mengolok, menghina, serta merendahkan di antara para pemeluk agama, meskipun keyakinan yang mereka miliki sangat jauh berbeda.

\section{Pengaruh negatif Murjiah}

Selain menimbulkan dampak positif, seperti disebutkan di muka, aliran Murji'ah juga menimbulkan dampak negatif. Di antara pengaruh negatif yang datang dari kaum Murjiah dewasa ini adalah: pertama, menanamkan Budaya taklid Secara bahasa kata

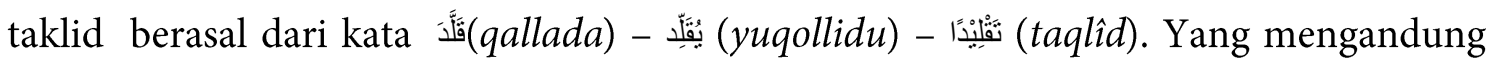
arti mengalungi, menghiasi, meniru, menyerahkan, dan mengikuti. Menurut Ulama Ushul Fiqh taqlid adalah penerimaan perkataan seseorang sedangkan engkau tidak mengetahui dari mana asal kata itu" (Khallaf, 1968). Suatu hal yang biasa ketika ada anak yang lahir dari orang tua muslim juga dikatakan seorang muslim. Padahal mereka belum tahu tentang apa itu Islam bahkan kadang sampai masa dewasanya. Khususnya mereka yang dari kecil sangat sedikit mengenyam pendidikan keagamaan. Memeluk Islam hanya ikut-ikutan atau bisa dibilang turunan. Ketika ditanya tentang agama, mereka menjawab "Islam" bahkan ada yang memberi label Ahlus Sunnah Wa Jama'ah tanpa lebih mengetahui semuanya. Padahal dalam aliran Ahlu Sunnah Wa Al-Jama'ah sendiri tidak diperbolehkan taklid dalam akidah. Kebolehan taklid dalam akidah hanya ditemukan dalam ajaran Murji'ah sebagaimana sebagian pendapat di atas. 
Kedua, penundaan dan penangguhan (al-irja') cenderung menimbulkan kemalasan. Menunda pekerjaan baik dalam urusan dunia maupun akhirat adalah perbuatan yang kurang baik, apapun bentuknya. Sebab akan menyisakan tugas di lain waktu. Apalagi dalam hal taubat, dampaknya sangat membahayakan terhadap keselamatan diri sendiri. Namun ketika hal ini mendapat harapan positif, tidak akan masuk neraka, menyebabkan seseorang enggan melakukan amal kebajikan. Sebab telah dijamin pahala syurga. Sehingga sifat pemalas akan timbul dengan sendirinya, padahal tidak sesuai dengan perintah Allah dan Rasulnya yang menganjurkan agar segera bertaubat sebelum datangnya ajal.

Ketiga, menghilangkan eksistensi hukum Allah di dunia. Ciri khas masyarakat modern adalah adanya kesadaran yang tinggi terhadap peraturan yang ada. Sebab, yang mengendalikan roda kehidupan adalah peraturan bukan manusia. Kalau diikuti faham model pemikiran kaum Murji'ah, terutama kelompok ektrim, keberadaan ayat dan hadis hukum tidak lagi bermakna, seperti menghukum pencuri dengan memotong tangan, menghukum penzina dengan rajam, menghukum bayar kafarat bagi pelanggarnya, dan lain-lain yang tersebut dalam Qur'an tidak ada gunanya. Sebab, seluruh kesalahan akan ditangguhkan hingga setelah menghadap Tuhan.

Dalam Islam mengenal dua bentuk hukuman (hudud) bagi pelanggarnya, yaitu di dunia dan akhirat. Keduanya mesti ditegakkan guna mencapai kesejahteraan hidup umat Islam. Hukuman di dunia diterapkan guna menjaga keselamatan jiwa manusia, sedangkan hukuman akhirat diperlakukan guna memberi balasan kenikmatan atau siksa. Dengan demikian akan menjaga terhadap keselamatan jiwa dan raga manusia, serta mewujudkan pengabdian yang tulus terhadap Allah. Sebagaimana dikatakan oleh asSyahrastany (Syahrastani, n.d.) Seorang ahli kalam pada zaman modern bahwa golongan ini selalu menunda amal perbuatan karena menganggap perbuatan tidak penting. Konsep yang dikemukakan kaum Murji'ah di atas mengandung makna negatif, karena kearifan yang diakibatkan oleh kehidupan beragama tidak nampak, sehingga menimbulkan sikap dan perilaku negatif bagi pemeluknya. Padahal salah satu tujuan beragama adalah tertanamnya asar ibadah dalam kehidupan sehari-hari. Perilaku semacam ini menyebabkan pelakunya berurusan dengan pihak keamanan. Tentu, tindakannya dapat mengusik kesucian ajaran yang dipeluknya.

Keempat, pengampunan Tuhan (aflatisme). Di zaman modern banyak ditemukan sekelompok orang yang terjerumus dalam kemaksiatan. Bahkan mereka 
tidak merasa berdosa atas apa yang dikerjakan adalah perbuatan nestapa. Orang yang bergelut dengan kemaksiatan ini ketika ditanya tentang apa yang dilakukannya, akan menjawab bahwa pengampunan Allah begitu luas dan tidak terbatas. Hal ini merupakan bagian dari pengaruh Murji'ah ekstrem yang mewajibkan pengampunan Allah terhadap segala dosa dengan konsep penangguhannya. Seperti terjadinya permusuhan umat Islam akibat terpecah belah ke dalam berbagai aliran. Sedangkan dampak terbesar adalah kemunduran di segala bidang bidang politik, ekonomi, keagaman, dan ilmu pengetahuan.

\section{Simpulan}

Setelah membahas tentang aliran Murjiah secara panjang lebar ternyata tidak semua aliran memiliki kecenderungan negative atau positif saja. Pada umumnya suatu aliran memiliki kelebihan dan kekrangan. Hanya saja jika sisi kelemahannya lebih dominan, maka kelompok tersebut dianggap jelek. Dengan kata lain, mereka memiliki raport "merah" yang sulit bertahan dalam waktu yang lama. Meskipun secara resmi tidak satupun kelompok masyarakat yang mengklaim kelompok Murjiah, namun pengaruh paham-pahamnya banyak terdapat di kalangan masyarakat hingga dewasa ini. Sama seperti kelompok Mu'tazilah, pengaruhnya sangat kuat terutama di kalangan intelektualisme muslim. $\mathrm{Hl}$ ini berbeda dengan kelompok Sunni, sebagai aliran terbesar di dunia Islam, kemudian Syi'ah sebagai kelompok terbesar kedua, serta Khawarij, sebagai kelompok ketiga, mereka masih eksis hingga saat ini. Nilai-nilai positif yang ada pada suatu aliran perlu dikembangkan dalam kehidupan modern sebagai salah satu warisan budaya Islam yang sangat tinggi, seperti sikap tolrenasi terhadap kelompok lain yang berbeda prinsip dan aliran guna menata kehidupan yang lebih maju dan demokratis. Sebaliknya nilai yang berakibat buruk atau kontraproduktif selayaknya dihindari dalam kehidupan manusia. Sebagaimana diajarkan al-Qur'an fa'tabiru ya ulil abshar 


\section{Referensi}

Amin, A. (1961). Fajrul Islam (1 ed.). Leiden: Srill.

Bukhari, I. (n.d.). Al-Jami Li al-Bukhari. Beirut: Darul Fikr.

Dawud, I. A. (1989). Sunan Abu Dawud. Beirut: Darul Fikr.

Hanafi. (2001). Pengantar Teologi Islam. Jakarta: Husni Zikra.

Imarah, M. (1991). Tayyarat al-Fikr al-Islamy. Mesir: Beirut.

Islam, E. (2002). Ensiklopedi Islam. Jakarta: Ichtiar Baru van Hoeve.

Jamrah, S. A. (2015). Studi Ilmu Kalam. Jakarta: Kencana.

Khallaf, A. W. (1968). Ilmu Ushul al Fiqh. Kuwait: Dar Al Kuwaitiyyah.

Nasution, H. (2011). Teologi Islam; Aliran-aliran, Sejarah, Analisis Perbandingan. Jakarta: UI-Press.

Nuruddin, M. A. (2012). Sejarah Pemikiran Islam (1 ed.). Jakarta: Amzah.

Ruslan, I. (2015). Sikap Permisif Teologi Murjiah dan Implikasinya Terhadap Moral Masyarakat. Jurnal Madania, 15(2).

Saeed, A. (2014). Pemikiran Islam Sebuah Pengantar. (S. Syamsuddin, Ed.). Yogyakarta: Baitul Hikmah Press.

Said, N. (2013). Teologi Islam Kontekstual- Transformatif. Fikrah, 1(1). https://doi.org/2354-6174, , 2014

Syahrastani, M. 'Abd al K. A.-. (n.d.). Al-Milal wa An-Nihal. Beirut: Darul Fikr.

Zahroh, M. A. (1996). Tarikh Mazahi al-Islamiyah fi Siyasah wa 'Aqaid (1 ed.). Beirut: Darul Fikr. 